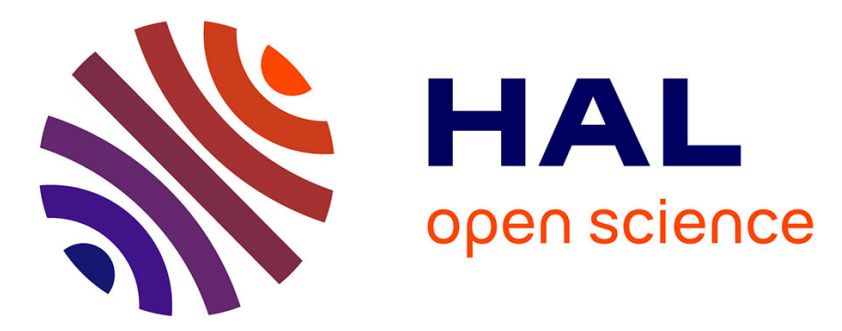

\title{
Thermophysical Properties, Hydrate and Phase Behaviour Modelling in Acid Gas-Rich Systems
}

Antonin Chapoy, Rod Burgass, Bahman Tohidi, Martha Hajiw, Christophe Coquelet

\section{- To cite this version:}

Antonin Chapoy, Rod Burgass, Bahman Tohidi, Martha Hajiw, Christophe Coquelet. Thermophysical Properties, Hydrate and Phase Behaviour Modelling in Acid Gas-Rich Systems. AGIS - 5th International Acid Gas Injection, May 2015, BANFF, Canada. hal-01152775

HAL Id: hal-01152775

https://hal-mines-paristech.archives-ouvertes.fr/hal-01152775

Submitted on 12 Jan 2016

HAL is a multi-disciplinary open access archive for the deposit and dissemination of scientific research documents, whether they are published or not. The documents may come from teaching and research institutions in France or abroad, or from public or private research centers.
L'archive ouverte pluridisciplinaire $\mathbf{H A L}$, est destinée au dépôt et à la diffusion de documents scientifiques de niveau recherche, publiés ou non, émanant des établissements d'enseignement et de recherche français ou étrangers, des laboratoires publics ou privés. 


\title{
Thermophysical Properties, Hydrate and Phase Behaviour Modelling in Acid Gas-Rich Systems
}

\author{
Antonin Chapoy ${ }^{1,2 *}$, Rod Burgass ${ }^{1}$, Bahman Tohidi $^{1}$ \\ Martha Hajiw ${ }^{1,2}$, Christophe Coquelet ${ }^{2}$ \\ ${ }^{1}$ Hydrates, Flow Assurance \& Phase Equilibria Research Group, Institute of Petroleum \\ Engineering, Heriot-Watt University, Edinburgh EH14 4AS, Scotland, UK \\ ${ }^{2}$ Mines ParisTech, PSL Research University CTP, Centre Thermodynamique des Procédés - \\ Département Énergétique et Procédés, Fontainebleau, France
}

\begin{abstract}
In this communication we present experimental techniques, equipment and thermodynamic modelling for investigating systems with high acid gas concentrations and discuss experimental results on the phase behaviour and thermo-physical properties of acid gas-rich systems. The effect of high $\mathrm{CO}_{2}$ concentration on density and viscosity were experimentally and theoretically investigated over a wide range of temperature and pressures. A corresponding-state model was developed to predict the viscosity of the stream and a volume corrected equation of state approach was used to calculate densities. The phase envelope and the hydrate stability (in water saturated and under-saturated conditions to assess dehydration requirements) of some acid gas-rich fluids were also experimentally determined to test a generalized model, which was developed to predict the phase behaviour, hydrate dissociation pressures and the dehydration requirements of acid gas rich gases.
\end{abstract}

\subsection{Introduction}

As the global demand for natural gas is forecasted to steadily grow, the demand will be met by supplies produced from "unconventional" gases. With sour gas fields worldwide accounting for some $40 \%$ of natural gas reserves, the development and production of these reserves are under very serious consideration (Lallemand et al. 2012). The main challenges facing companies developing these fields with high concentrations of acid gases are reservoir engineering, phase behaviour predictions, processing and their removal from hydrocarbon streams, transportation and storage.

Due to the huge quantities of these gases produced and more stringent environmental regulations these gases cannot be flared, thus one of the most viable options is to inject them back into the reservoir for storage as well as enhance oil recovery (EOR). For acid gases, the disposal alternatives are: injection of compressed acid gas into the formation; disposal of acid gases with the formation water or solubilise acid gases into a light hydrocarbon solvent and use the solvent as a miscible flood EOR (Jamaluddin et al., 1996). In fields with high concentration of $\mathrm{H}_{2} \mathrm{~S}$ dehydration using glycols may lead to additional problems such as corrosion and the release of $\mathrm{H}_{2} \mathrm{~S}$ when it is regenerated. In such cases the knowledge of

\footnotetext{
*To whom correspondence should be addressed: e-mail: antonin.chapoy@pet.hw.ac.uk
} 
multicomponent gas water content and the optimum injection pressure will be essential. Furthermore reinjection into new reservoirs (such as Kashagan field in Kazakhstan) will require extremely high pressures. The design of such compressors requires accurate thermophysical properties of multicomponent mixtures.

However limited data are available on the phase and hydrate behaviours of $\mathrm{CO}_{2}$-rich or acid gas systems to validate existing thermodynamic models. Therefore the applicability of the existing models and their uncertainties can lead to over or undersized designs. In this communication we present experimental techniques, equipment and thermodynamic modelling for investigating systems with high $\mathrm{CO}_{2}$ or $\mathrm{H}_{2} \mathrm{~S}$ concentrations, including gas reservoirs with high $\mathrm{CO}_{2}$ content and/or $\mathrm{CO}_{2}$-rich systems from capture processes. In particular, experimental measurements of the locus of incipient hydrate-liquid water-vapour curve for a methane $-\mathrm{H}_{2} \mathrm{~S}$ binary system and a $\mathrm{CO}_{2}$-rich natural gas $\left(70\right.$ mole $\%$ of $\mathrm{CO}_{2}$ and 30 mole $\%$ of light hydrocarbons $\mathrm{C}_{1}$ to $\mathrm{nC}_{4}$ ) in equilibrium with liquid water are presented at pressures up to $35 \mathrm{MPa}$. Experimental data are reported for water content in equilibrium with hydrates at about 150 bar and temperature range from 233 to $283 \mathrm{~K}$. Density and viscosity of the mixture were also measured from 253 to $423 \mathrm{~K}$ at pressure up to $124 \mathrm{MPa}$. An example of dry ice formation in a $\mathrm{CO}_{2}$-rich natural gas will be also described.

The Cubic-Plus-Association (CPA-EoS) or the Soave-Redlich-Kwong (SRK) equation of state combined with the solid solution theory of van der Waals and Platteeuw (1959) as developed by Parrish and Prausnitz (1972) was employed to model the fluid and hydrate phase equilibria as previously described by Chapoy et al. (2012). The predictions of the thermodynamic model were compared with the experimentally measured properties (saturation pressure, dew point, frost points, hydrates). A corresponding state model developed to predict viscosity of the $\mathrm{CO}_{2}$-rich stream (Chapoy et al. 2013) was used to evaluate the new viscosity data.

\subsection{Experimental Setups and Procedures}

The majority of the setups and procedures used in this paper were described in detail in Chapoy et al. (2005), Chapoy et al. (2012), Chapoy et al. (2013) and Hajiw et al. (2014). A brief description of each setup is given below.

\subsubsection{Saturation and Dew Pressure Measurements and Procedures}

The equilibrium setup consisted of a piston-type variable volume (maximum effective volume of $300 \mathrm{ml}$ ), titanium cylindrical pressure vessel with mixing ball, mounted on a horizontal pivot with associated stand for pneumatic controlled rocking mechanism. Rocking of the cell through 180 degrees at a constant rate, and the subsequent movement of the mixing ball within it, ensured adequate mixing of the cell fluids. Cell volume, hence pressure, can be adjusted by injecting/withdrawal of liquid behind the moving piston. The rig has a working temperature range of 210 to $370 \mathrm{~K}$, with a maximum operating pressure of $69 \mathrm{MPa}$. System temperature is controlled by circulating coolant from a cryostat within a jacket surrounding the cell. The equilibrium cell and pipework were thoroughly insulated to ensure constant temperature. The temperature was measured and monitored by means of a PRT (Platinum Resistance Thermometers) located within the cooling jacket of the cell (accuracy of $\pm 0.05 \mathrm{~K}$ ). A Quartzdyne pressure transducer with an accuracy of $\pm 0.05 \mathrm{MPa}$ was used to monitor pressure. The bubble point was determined by changing the volume of the cell and finding the break over point in the pressure vs. volume curve as shown in Figure 1.

A typical test to determine the dew point is as follows: To obtain the dew point using the isochoric method the cell is loaded with the test sample and is set to 5 degrees above the 
estimated dew point temperature. The cell is cooled until the system has clearly become two phase. The cell temperature is then step heated, allowing sufficient time for equilibration, until the system has clearly become single phase again. Throughout the process the cell is rocked using a pneumatic pivoting system to ensure all of the cell constituents are thoroughly mixed and equilibrium is reached. The system pressure and temperature are recorded every minute using a logging program. The recorded data is then processed to determine the system pressure at each temperature step. This process results in two traces with very different slopes on a pressure versus temperature $(\mathrm{P} / \mathrm{T})$ plot, one in the single phase and one in the 2 phases region. The point where these two traces intersect is taken as the dew point (Figure 2).

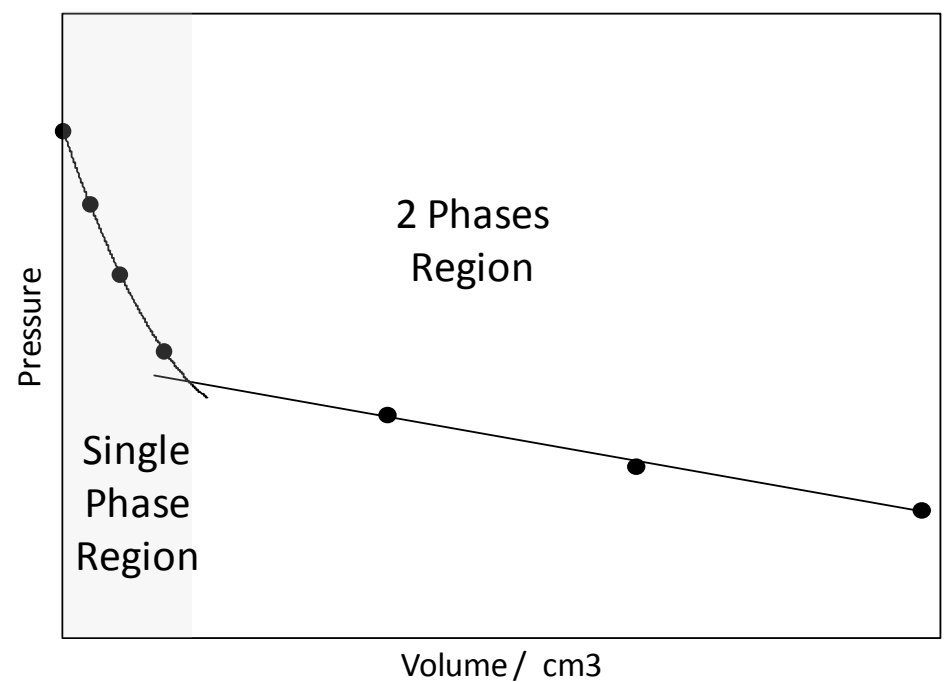

Figure 1. Plot showing an example of bubble point determination from plot of change in cell pressure versus volume

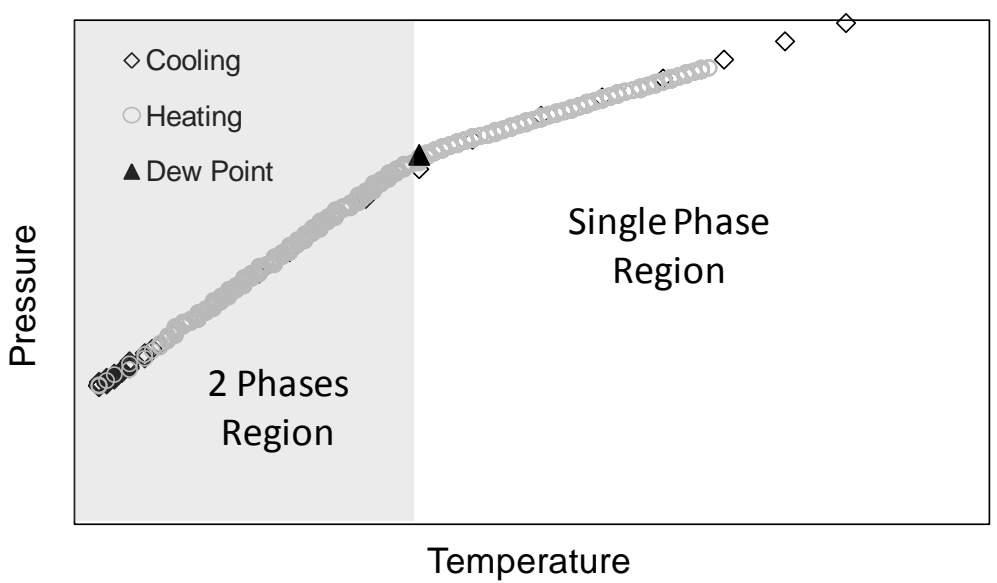

Figure 2. Plot showing an example of dew point determinations from equilibrium stepheating data using the isochoric method.

\subsubsection{Hydrate dissociation Measurements and Procedures}

Dissociation point measurements were conducted using the isochoric step-heating method. The phase equilibrium is achieved in a cylindrical cell made of Hastelloy equipped with a 
pressure magnetic mixer. A detailed description of the apparatus and test procedure can be found elsewhere (Hajiw et al., 2014; Chapoy et al., 2013). The weight of the fluids (i.e., water and the multicomponent fluid) injected are recorded prior to any measurements and the overall feed composition can thus be calculated.

A typical test to determine the dissociation point is as follows: the cell is cleaned and dried. About half of the volume of the cell is initially preloaded with water, prior to applying vacuum to the system. Then, the fluids are loaded into the cell to reach the first desired pressure the temperature is then increased stepwise, slowly enough to allow equilibrium to be achieved at each temperature step. At temperatures below the point of complete dissociation, gas is released from decomposing hydrates, giving a marked rise in the cell pressure with each temperature step (Figure 3). However, once the cell temperature has passed the final hydrate dissociation point, and all hydrates have disappeared from the system, a further rise in the temperature will result only in a relatively small pressure rise due to thermal expansion. This process results in two traces with very different slopes on a pressure versus temperature $(\mathrm{P} / \mathrm{T})$ plot; one before and one after the dissociation point. The point where these two traces intersect (i.e., an abrupt change in the slope of the P/T plot) is taken was the dissociation point (see Figure 3).

For a full discussion on accuracy and uncertainties of hydrate dissociations measurements the reader is invited to check the work of Stringari et al. (2014) or Hajiw, (2014).

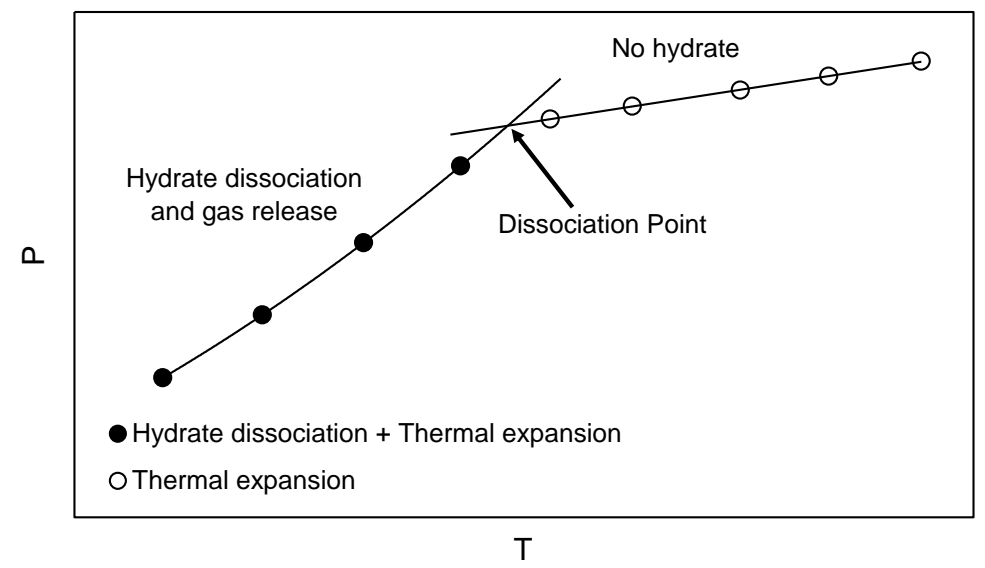

Figure 3. Dissociation point determination from equilibrium step-heating data. The equilibrium dissociation point is determined as being the intersection between the hydrate dissociation (pressure increase as a result of gas release due to temperature increase and hydrate dissociation, as well as thermal expansion) and the linear thermal expansion (no hydrate) curves.

\subsubsection{Water Content Measurements and Procedures}

The core of the equipment for water content measurement has been originally described by Chapoy et al. (2012) and Burgass et al. (2014). The setup comprises of an equilibrium cell and a device for measuring the water content of equilibrated fluids passed from the cell. The equilibrium cell is similar to the one described in the saturation pressure measurements. The moisture/water content measurement set-up consists of a heated line, a Tuneable Diode Laser Adsorption Spectroscopy (TDLAS) from Yokogawa and a flow meter. The estimated experimental accuracy of water content is $\pm 5 \mathrm{ppm}$ mole. 


\subsubsection{Viscosity and density Measurements and Procedures}

All viscosity and density measurements were conducted using an in-house designed and constructed set-up; a schematic view is shown in Figure 4. This setup has been designed to have a maximum working pressure of $200 \mathrm{MPa}$ (density measurements are limited to 140 $\mathrm{MPa}$ ) and a maximum working temperature of $473.15 \mathrm{~K}$. For these measurements, the set-up was located inside the chamber of an oven, manufactured by BINDER GmbH, capable of being used at temperatures from 200 to $443.15 \mathrm{~K}$. The set-up is comprised of two small cylinders, with volumes of $15 \mathrm{~cm}^{3}$, connected to each other through a capillary tube with a measured length of 14.781 metres and a calculated internal diameter of $0.29478 \mathrm{~mm}$. An oscillating U tube densitometer Anton Paar DMA-HPM is connected to the set-up.

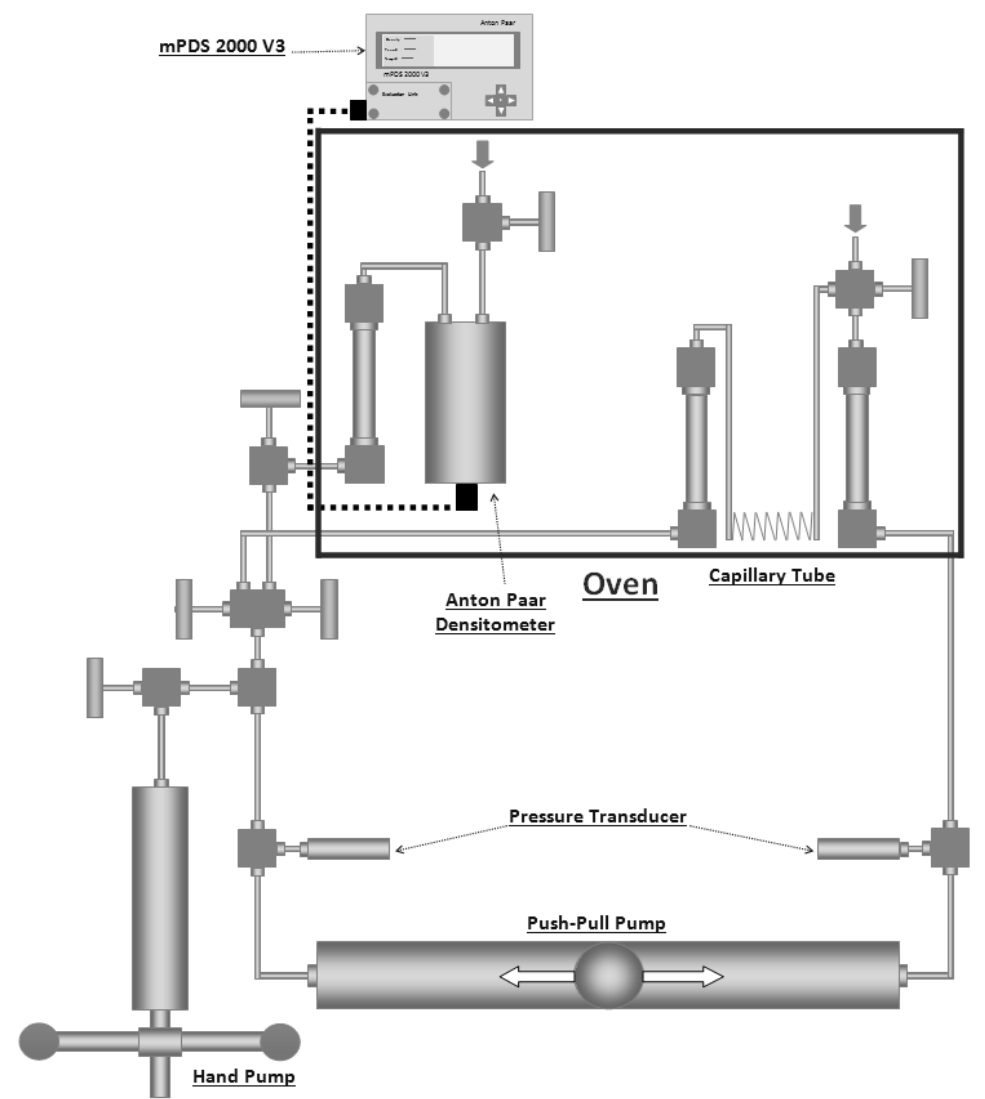

Figure 4. Schematic drawing of the viscosity - density set-up

\subsubsection{Frost Point Measurements and Procedures}

The equipment and procedures used for determining the frost points of the solid $\mathrm{CO}_{2}$ has been originally described by Longman et al. (2011). A stainless steel equilibrium cell, which is approximately $11 \mathrm{~cm}^{3}$ in volume, is submerged in an ethanol bath. The temperature of the ethanol is controlled by a thermostat (LAUDA Proline RP 1290) with a working temperature range 183 to $320 \mathrm{~K}$ and an accuracy of $\pm 0.01 \mathrm{~K}$. The ethanol is stirred continuously to maintain a homogeneous temperature distribution in the bath. The equilibrium cell temperature is measured by a platinum resistance thermometer located inside the equilibrium cell. The accuracy of the measured temperature is $\pm 0.05 \mathrm{~K}$. The temperature probe was calibrated against a Prema 3040 precision thermometer and checked by measuring the triple 
point of pure $\mathrm{CO}_{2}$. The equilibrium cell pressure is measured by a Quartzdyne pressure transducer.

\subsubsection{Materials}

Methane and hydrogen sulphide were purchased from Air Liquide with 99.995 vol\% certified purity for methane and $99.5 \mathrm{vol} \%$ for hydrogen sulphide. Deionised water was used in all experiments. Carbon dioxide $\left(\mathrm{CO}_{2}\right)$ has been purchased from BOC with a certified purity higher than 99.995 vol\%. Compositions of the synthetic mixtures are given in Table 3 .

Table 1. Composition, mole \% each component, of the multicomponent mixtures

\begin{tabular}{lccc}
\hline Components & $\begin{array}{l}\text { Synthetic Mix 1 } \\
\text { (from Hajiw et al., 2014) }\end{array}$ & $\begin{array}{l}\text { Synthetic Mix 2 } \\
\text { (from Chapoy et al., 2013) }\end{array}$ & Synthetic Mix 3 \\
\hline $\mathrm{CO}_{2}$ & - & Balance $(89.83)$ & Balance $(69.99)$ \\
$\mathrm{H}_{2} \mathrm{~S}$ & 20.0 & - & - \\
Methane & 80.0 & - & $20.02( \pm 0.11 \%)$ \\
Ethane & - & - & $6.612( \pm 0.034 \%)$ \\
Propane & - & - & $2.58( \pm 0.013 \%)$ \\
i-Butane & - & - & $0.3998( \pm 0.004 \%)$ \\
n-Butane & - & $3.07( \pm 0.04 \%)$ & $0.3997( \pm 0.004 \%)$ \\
Nitrogen & - & $5.05( \pm 0.01 \%)$ & - \\
Oxygen & - & $2.05( \pm 0.06 \%)$ & - \\
Argon & - & 100 & - \\
\hline Total & 100 & & 100 \\
\hline
\end{tabular}

\subsection{Thermodynamic and Viscosity Modelling}

\subsubsection{Fluid and Hydrate Phase Equilibria Model}

A detailed description of the original thermodynamic framework used in this work can be found elsewhere (Haghighi et al., 2009; Chapoy et al., 2014). In summary, the thermodynamic model is based on the uniformity of fugacity of each component throughout all the phases. The CPA-EoS or the SRK-EoS (if no water is present) is used to determine the component fugacities in fluid phases. The hydrate phase is modelled using the solid solution theory of van der Waals and Platteeuw (1954) as developed by Parrish and Prausnitz (1972). The CPA-EoS binary interaction parameters between components were determined using the group contribution method developed by Jaubert and co-workers. The model to calculate frost points was described by Longman et al. (2011). The developed model can predict accurately the distribution of water in the $\mathrm{CO}_{2}$ or $\mathrm{H}_{2} \mathrm{~S}$-rich phase and solubility of $\mathrm{CO}_{2}$ or $\mathrm{H}_{2} \mathrm{~S}$ in the aqueous phase below and above the critical point of pure $\mathrm{CO}_{2}$ as shown in Figures 5 and 6. 

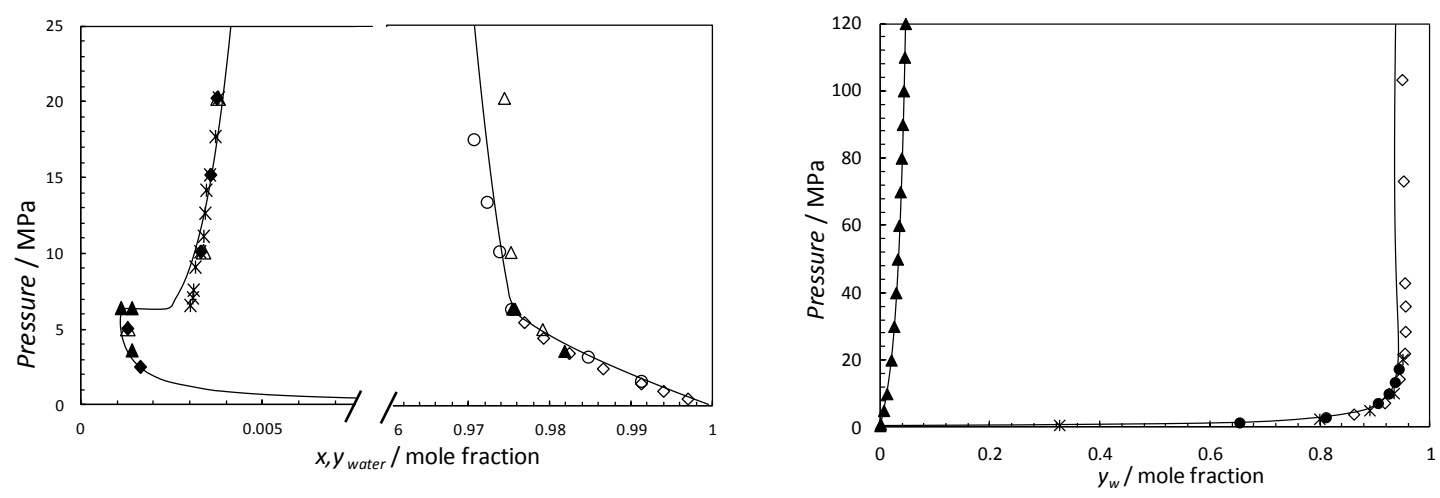

Figure 5. Pxy, Phase equilibria in the carbon dioxide + water system at $298.15 \mathrm{~K}$ left) and $423.15 \mathrm{~K}$ (right). Black Lines: Model predictions. Left figure: ( $\bullet$ ) Experimental data from Wiebe and Gaddy (1941); $(\triangle)$ Experimental data from Gillepsie and Wilson (1982) ; ( $\mathbf{\Delta})$ Experimental data from Nakayama et al. (1987) ; ( $($ ) Experimental data from King et al. (1992) ; (O): Experimental data from Hou et al. (2013) ; $\diamond)$ : Experimental data from Valtz et al. (2004). Right figure: $(\diamond)$ : Experimental data from Takenouchi and Kennedy (1964); ( $\star$ Experimental data from Gillepsie and Wilson (1982); ( $\diamond)$ : Experimental data from Tabasinejad et al. (2011) at $422.98 \mathrm{~K} ;(\mathbf{O})$ : Experimental data from Hou et al. (2013).

(A): calculated data Duan and Sun (2003)
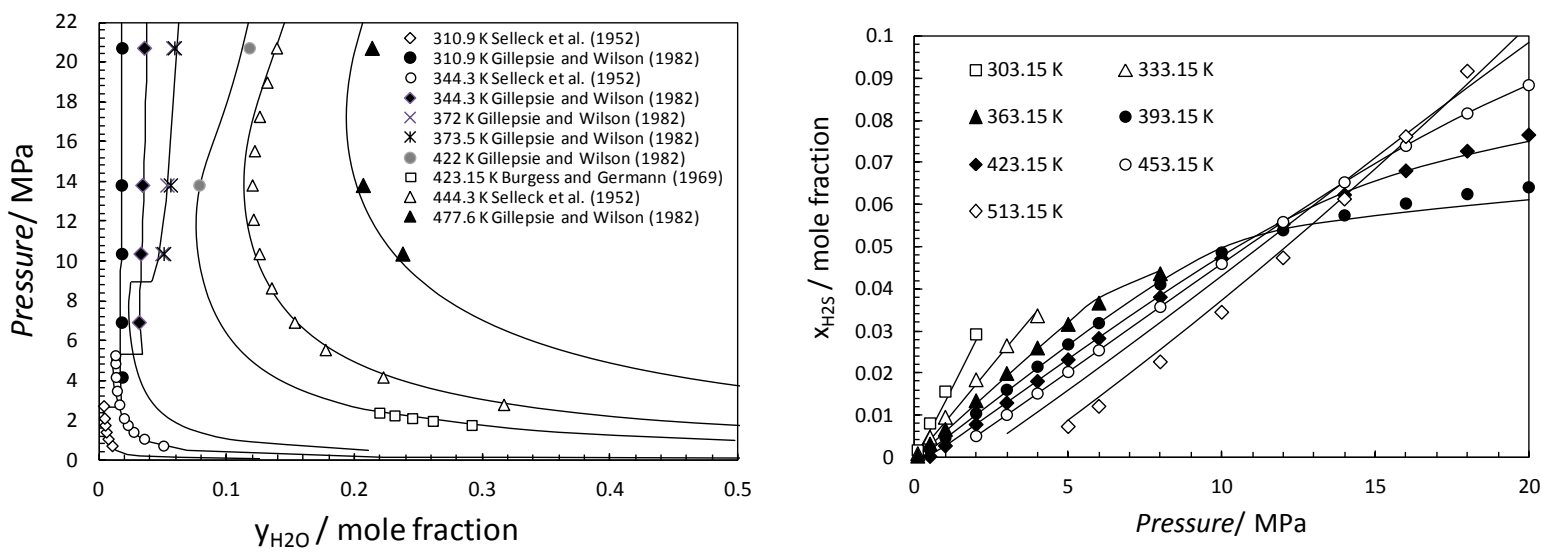

Figure 6. Pxy, Phase equilibria in the hydrogen sulphide + water system. Black Lines: Model predictions. Left figure: water content in the $\mathrm{H}_{2} \mathrm{~S}$ rich phases. Right figure: $\mathrm{H}_{2} \mathrm{~S}$ solubility in the aqueous phase. (A): calculated data Duan et al. (2007)

In this work, the molar volume for $\mathrm{CO}_{2}$ or a $\mathrm{CO}_{2}$-rich mixture, as calculated by the SRK-EoS, is corrected using the exact volume of pure $\mathrm{CO}_{2}$ at the given $\mathrm{T}$ and $\mathrm{P}$.

$$
V^{\text {new }}=V^{\text {EoS }}-V^{C}
$$

Where $V^{E o S}$ is the molar volume obtained from the equation of state. The correction of molar volume in the Eq. (2), $V^{c}$, is defined as:

$$
V^{C}=\sum_{k=1}^{N} x_{i} V_{i}^{C}
$$


$x_{i}$ is the composition of component $i$ in the phase in which the volume is calculated. For $\mathrm{CO}_{2}$, $V_{i}^{c}$ is defined by

$$
V_{\mathrm{CO}_{2}}^{C}=V_{\text {Pure } \mathrm{CO}_{2}}^{\mathrm{EOS}}-V^{\mathrm{MBWR}}
$$

For the other components, $V_{i}^{c}$ was set to 0 . The carbon dioxide density is computed from the MBWR equation in the form suggested by Ely et al. (1987):

$P=\sum_{n=1}^{9} a_{n}(T) \rho^{n}+\sum_{n=10}^{15} a_{n}(T) \rho^{2 n-17} e^{-\gamma \rho^{2}}$

\subsubsection{Viscosity Model}

To model viscosity, our proposed model is a modification of the corresponding state viscosity model described in Pedersen and Christensen (2007). According to the corresponding states principles applied to viscosity, the reduced viscosity, $\eta_{r}=\eta(T, P) / \eta_{C}$, for two components at the same reduced pressure, $P_{r}=P / P_{C}$ and reduced temperature, $T_{r}=T / T_{C}$, will be the same.

$\eta_{r}=f\left(T_{r}, P_{r}\right)$

Based on the dilute gases considerations and kinetic theory, viscosity at critical point can be approximated as:

$\eta_{c} \approx \frac{P_{c}^{2 / 3} M^{1 / 2}}{T_{c}^{1 / 6}}$

Where, $\mathrm{M}$ denotes the Molecular weight. Thus, the reduced viscosity can be expressed as:

$$
\eta_{r}=\frac{\eta(T, P)}{\eta_{C}}=\frac{\eta(T, P) T_{c}^{1 / 6}}{P_{c}^{2 / 3} M^{1 / 2}}
$$

For one component as a reference component if the function $f$ in Eq. (5) is known, it is possible to calculate the viscosity of any other components, such as component $i$, at any pressure and temperature. Thus,

$$
\eta_{i}=\frac{\left(\frac{P_{c, i}}{P_{c, o}}\right)^{2 / 3}\left(\frac{M_{i}}{M_{o}}\right)^{1 / 2}}{\left(\frac{T_{c, i}}{T_{c, o}}\right)^{1 / 6}} \eta_{0}\left(\frac{T T_{c o}}{T_{c, i}}, \frac{P P_{c o}}{P_{c, i}}\right)
$$

Where, 0 refers to the reference component. Methane with the viscosity data published by Hanley et al. (1975) was selected as the reference fluid in the original Pedersen model. In this work, $\mathrm{CO}_{2}$ with the viscosity data published by Fenghour et al. (1998) has been selected as the reference fluid as $\mathrm{CO}_{2}$ is the major constituent of the stream. The viscosity of $\mathrm{CO}_{2}$ as a function of density at given $\mathrm{T}$ and $\mathrm{P}$ can be calculated from the following equation:

$$
\eta(\rho, T)=\eta_{0}(T)+\Delta \eta(\rho, T)
$$


Where, $\eta_{0}(\mathrm{~T})$ is the zero-density viscosity which can be obtained from the following equation:

$\eta_{0}(T)=\frac{1.00697 T^{1 / 2}}{\psi_{\eta}^{*}\left(T^{*}\right)}$

In this equation, the zero-density viscosity is in units of $\mu \mathrm{Pa}$.s and temperature, $T$, in $\mathrm{K}$. The reduced effective cross section, $\psi_{\eta}^{*}\left(T^{*}\right)$, is represented by the empirical equation:

$\ln \psi_{\eta}^{*}\left(T^{*}\right)=\sum_{i=0}^{4} a_{i}\left(\ln T^{*}\right)^{i}$

Where the reduced temperature, $\mathrm{T}^{*}$, is given by:

$\mathrm{T}^{*}=\mathrm{kT} / \varepsilon$

And the energy scaling parameter, $\varepsilon / \mathrm{k}=251.196 \mathrm{~K}$. The coefficients $a_{i}$ are listed in Table 1 . The second contribution in Eq. (9) is the excess viscosity, $\Delta \eta(\rho, T)$, which describes how the viscosity can change as a function of density outside of the critical region. The excess viscosity term can be correlated as follows:

$$
\Delta \eta(\rho, T)=d_{11} \rho+d_{21} \rho^{2}+\frac{d_{64} \rho^{6}}{T^{* 3}}+d_{81} \rho^{8}+\frac{d_{82} \rho^{8}}{T^{*}}
$$

Where, the temperature is in Kelvin, the density in $\mathrm{kg} / \mathrm{m}^{3}$ and the excess viscosity in $\mu$ Pa.s. The coefficients $d_{i j}$ are shown in Table 2 .

Table 1. Values of Coefficients $a_{i}$ for $\mathrm{CO}_{2}$ in Table 2. Values of coefficients $\mathrm{d}_{\mathrm{ij}}$ in Eq. (13) Eq. (11)

\begin{tabular}{ll}
\hline $\mathrm{i}$ & $\mathrm{a}_{\mathrm{i}}$ \\
\hline 0 & 0.235156 \\
1 & -0.491266 \\
2 & $5.211155 \times 10^{-2}$ \\
3 & $5.347906 \times 10^{-2}$ \\
4 & $-1.537102 \times 10^{-2}$ \\
\hline
\end{tabular}

\begin{tabular}{ll}
\hline $\mathbf{d}_{\mathbf{i j}}$ & Value \\
\hline $\mathbf{d}_{\mathbf{1 1}}$ & $0.4071119 \times 10^{-2}$ \\
$\mathbf{d}_{\mathbf{2 1}}$ & $0.7198037 \times 10^{-4}$ \\
$\mathbf{d}_{\mathbf{6 4}}$ & $0.2411697 \times 10^{-16}$ \\
$\mathbf{d}_{\mathbf{8 1}}$ & $0.2971072 \times 10^{-22}$ \\
$\mathbf{d}_{\mathbf{8 2}}$ & $-0.1627888 \times 10^{-22}$ \\
\hline
\end{tabular}

The corresponding states principle expressed in Eq. (8) for the viscosity of pure components works well for mixtures. Pedersen et al. (1984) have used the following expression to calculate the viscosity of mixtures at any pressure and temperature.

$$
\eta_{\text {mix }}=\frac{\left(\frac{P_{c, \text { mix }}}{P_{c, o}}\right)^{2 / 3}\left(\frac{M_{\text {mix }}}{M_{o}}\right)^{1 / 2}}{\left(\frac{T_{c, \text { mix }}}{T_{c, o}}\right)^{1 / 6}} \frac{\alpha_{\text {mix }}}{\alpha_{o}} \eta_{0}\left(T_{0}, P_{0}\right)
$$

Where

$$
P_{o}=\frac{P P_{c o}}{P_{c, \text { mix }}} \frac{\alpha_{0}}{\alpha_{\text {mix }}} \text { and } T_{o}=\frac{T T_{c o}}{T_{c, \text { mix }}} \frac{\alpha_{0}}{\alpha_{\text {mix }}}
$$

The critical temperature and pressure for mixtures, according to recommended mixing rules by Murad and Gubbins (1977), can be found from: 


$$
\begin{gathered}
T_{c, \text { mix }}=\frac{\sum_{i}^{N} \sum_{j}^{N} z_{i} z_{j}\left[\left(\frac{T_{c, i}}{P_{c, i}}\right)^{1 / 3}+\left(\frac{T_{c, j}}{P_{c, j}}\right)^{1 / 3}\right]^{3} \sqrt{T_{c, i} T_{c, j}}}{\sum_{i}^{N} \sum_{j}^{N} z_{i} z_{j}\left[\left(\frac{T_{c, i}}{P_{c, i}}\right)^{1 / 3}+\left(\frac{T_{c, j}}{P_{c, j}}\right)^{1 / 3}\right]^{3}} \\
P_{c, \text { mix }}=\frac{8 \sum_{i}^{N} \sum_{j}^{N} z_{i} z_{j}\left[\left(\frac{T_{c, i}}{P_{c, i}}\right)^{1 / 3}+\left(\frac{T_{c, j}}{P_{c, j}}\right)^{1 / 3}\right]^{3} \sqrt{T_{c, i} T_{c, j}}}{\left(\sum_{i}^{N} \sum_{j}^{N} z_{i} z_{j}\left[\left(\frac{T_{c, i}}{P_{c, i}}\right)^{1 / 3}+\left(\frac{T_{c, j}}{P_{c, j}}\right)^{1 / 3}\right]^{3}\right]^{2}}
\end{gathered}
$$

The mixture molecular weight is found from

$$
M_{\text {mix }}=1.304 \times 10^{-4}\left(\bar{M}_{w}^{2.303}-\bar{M}_{n}^{2.303}\right)+\bar{M}_{n}
$$

Where $\bar{M}_{w}$ and $\bar{M}_{n}$ are the weight average and number average molecular weights, respectively.

$$
\begin{aligned}
& \bar{M}_{w}=\frac{\sum_{i}^{N} z_{i} M_{i}^{2}}{\sum_{i}^{N} z_{i} M_{i}} \\
& \bar{M}_{n}=\sum_{i}^{N} z_{i} M_{i}
\end{aligned}
$$

The parameter $\alpha$ for mixtures in Eq. (14) can be found from:

$$
\alpha_{\text {mix }}=1.000+7.378 \times 10^{-3} \rho_{r}^{1.847} M_{\text {mix }}^{0.5173}
$$

Also, $\alpha$ for the reference fluid can be found from Eq. (21) by replacing the molecular weight of the mixture with that of the reference fluid, carbon dioxide. The reduced density, $\rho_{r}$, is defined as:

$$
\rho_{r}=\frac{\rho_{0}\left(\frac{T_{c o}}{T_{c, \text { mix }}}, \frac{P P_{c o}}{P_{c, \text { mix }}}\right)}{\rho_{c 0}}
$$

The critical density of carbon dioxide, $\rho_{0}$, is equal to $467.69 \mathrm{~kg} / \mathrm{m}^{3}$. The Modified BenedictWebb-Rubin (MBWR) equation of state has been applied for computing the reference fluid density, $\rho_{0}$, at the desired pressure and temperature of $\frac{P P_{c o}}{P_{c, m i x}}, \frac{T T_{c o}}{T_{c, m i x}}$.

The procedure below should be followed to calculate the viscosity of $\mathrm{CO}_{2}$ systems with impurities by the proposed corresponding state principle model:

1. Calculate the $\mathrm{T}_{\mathrm{cmix}}, \mathrm{P}_{\mathrm{cmix}}$ and $\mathrm{M}_{\text {mix }}$ from Eq. (16), (17) and (18), respectively. 
2. Obtain the $\mathrm{CO}_{2}$ density at $\frac{P P_{c o}}{P_{c, \text { mix }}}, \frac{T T_{c o}}{T_{c, \text { mix }}}$ from the MBWR EOS and calculate the reduced density from Equation (22).

3. The mixture parameter, $\alpha_{\text {mix }}$, and $\alpha_{0}$ should be calculated from Eq. (21).

4. The reference pressure and temperature, $\mathrm{P}_{0}$ and $\mathrm{T}_{0}$, should be calculated from Equation (15).

5. Calculate the $\mathrm{CO}_{2}$ reference fluid, $\eta_{0}\left(P_{0}, T_{0}\right)$ in Eq. (14) from Eq. (9).

6. Calculate the mixture viscosity from Eq. (14).

\subsection{Results and Discussions}

All results were compared where possible with experimental values for pure methane, pure carbon dioxide, a synthetic $\mathrm{CO}_{2}$-rich fluid $\left(\mathrm{CO}_{2}: 89.83\right.$ mole\%; $\mathrm{O}_{2}: 5.05$ mole\%; Ar: 2.05 mole\%; $\mathrm{N}_{2}: 3.07$ mole\% from Chapoy et al., 2013) and a typical North Sea natural gas.

For a model to predict accurately the hydrate phase behaviour or transport properties, it is essential that the phase behaviour is correctly predicted, i.e. the phase region, bubble and dew lines. For example for hydrate calculation, the hydrate stability has very sharp temperature dependency above the bubble point, an error in estimating the saturation pressure will lead to high deviations in the hydrate phase behaviour. Viscosity models are also dependant on good density predictions, if a vapour-liquid behaviour is predicted instead of a saturated liquid it will also lead to very high deviations in viscosities. As shown in Figure 7, the $S R K-E O S$ model combined with the group contribution for $k_{i j}$ can predict the phase envelope of the multicomponent systems with good accuracy. The predictions are of greater accuracy for the system containing less carbon dioxide.

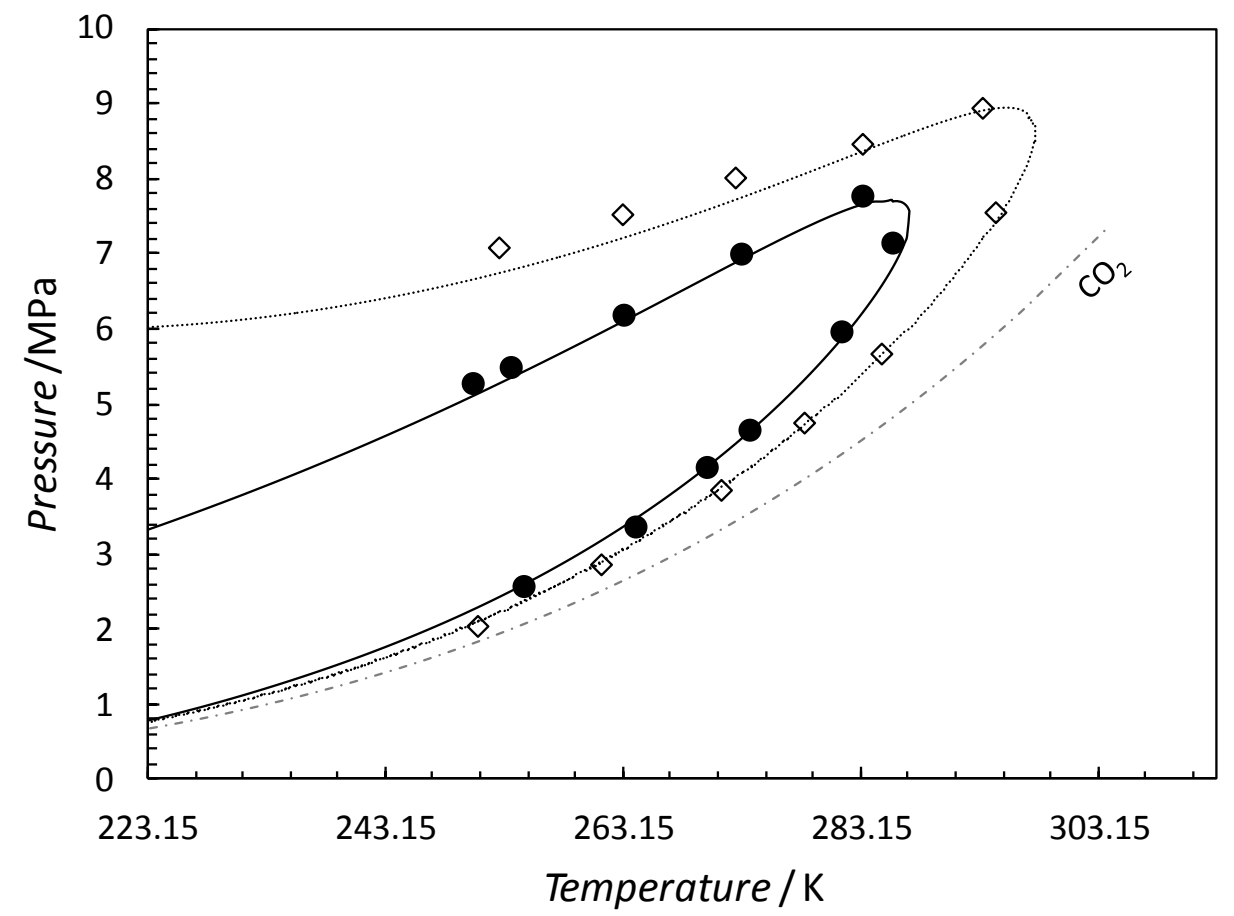

Figure 7. Experimental and predicted phase envelope of the $\mathrm{CO}_{2}$-rich mixture. ( $)$,Synthetic Mix 3. $(\diamond)$, Synthetic Mix 2. Black lines: bubble lines predictions using the SRK-EoS; Dotted black lines: dew lines predictions using the SRK-EoS; Grey broken lines: predicted vapour pressure of pure $\mathrm{CO}_{2}$ using the SRK-EoS. 


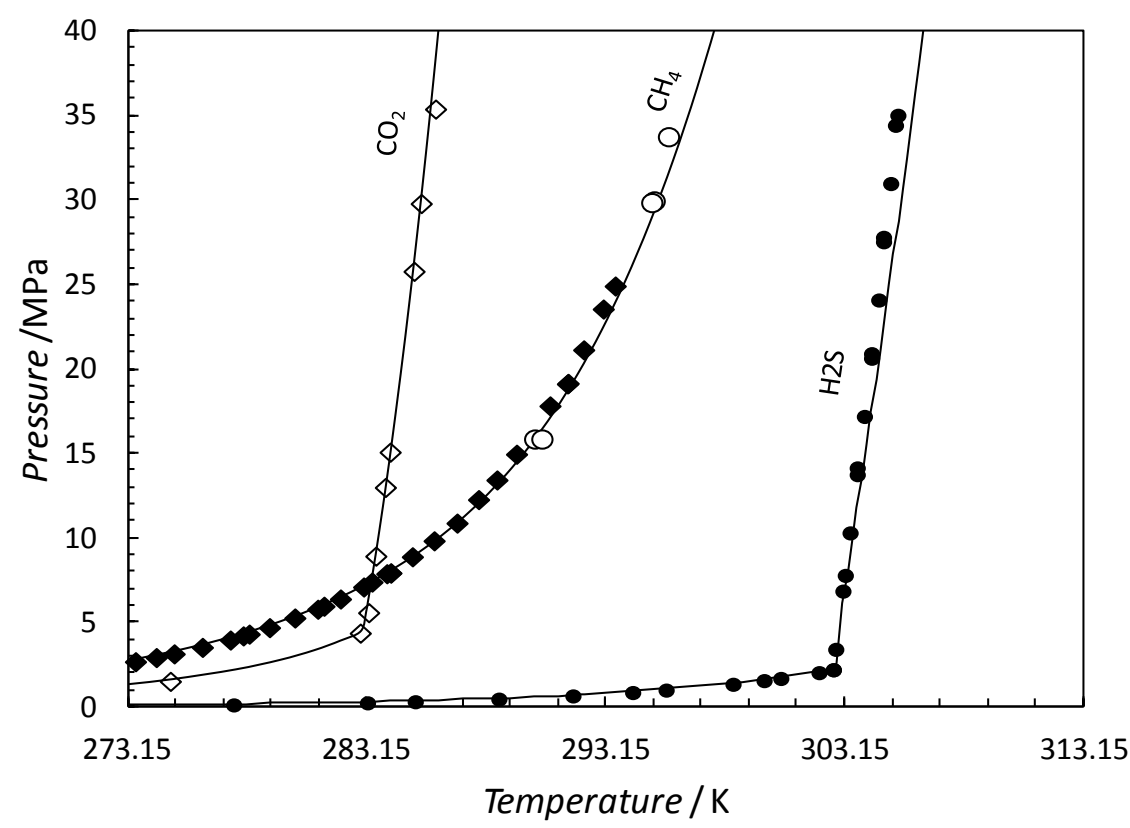

Figure 8. Experimental and predicted hydrate stability of $\mathrm{CO}_{2}, \mathrm{H}_{2} \mathrm{~S}$ and methane in equilibrium with liquid water. $(\diamond)$, pure $\mathrm{CO}_{2}$ hydrate stability zone (Chapoy et al. 2011); (O), pure $\mathrm{H}_{2} \mathrm{~S}$ hydrate stability zone (Selleck et al. 1952); (O): pure $\mathrm{CH}_{4}$ hydrate stability zone (Nixdorf and Oellrich, 1997);( ), pure $\mathrm{CH}_{4}$ hydrate stability zone (Marshall et al. 1964).

Methane, carbon dioxide and hydrogen sulphide are well known structure I hydrate formers. Hydrate phase equilibria of these systems have been extensively investigated and can be predicted with very high accuracy as seen in Figure 8. Multicomponent systems containing hydrogen sulphide are far scarcer. Hajiw et al. (2014) measured the hydrate dissociation conditions for a mixture of methane and hydrogen sulphide. Composition of the fluid is given in Table 1. As the solubility difference between methane and hydrogen sulphide is of several order of magnitude, the hydrate stability zone of this mixture is highly dependent on the fluid to water ratio as seen in Figure 9. The model has also been evaluated with the methane + hydrogen sulphide + carbon dioxide hydrate data reported by Sun et al. (2003). Like methane, carbon dioxide and hydrogen sulphide, and all their mixtures are predicted to form structure I hydrate. For these systems, the thermodynamic model is in excellent agreement with these experimental data (within $0.5 \mathrm{~K}$ ). The ratio between the water mole fraction and the mixture fraction can have a large effect if the concentration of $\mathrm{H}_{2} \mathrm{~S}$ and $\mathrm{CO}_{2}$ is in excess of 10 mole\%.

The experimental hydrate dissociation conditions for the synthetic mixtures 2 and 3 in equilibrium with water are plotted in Figure 11. Pure $\mathrm{CO}_{2}, \mathrm{CH}_{4}$ and synthetic mixture 2 form structure I hydrate whereas synthetic mixture 3 is predicted to form structure II because of the presence of larger hydrocarbon molecules (propane, i-butane and n-butane). It is also interesting to note that this system, depending on the water to gas ratio, should just enter the phase envelope of the system but displays at higher pressure a liquid like hydrate locus. The system is, over the full pressure range, more stable than pure $\mathrm{CO}_{2}$ or synthetic mixture, which form structure I. At low and intermediate pressure ( $\mathrm{P}<14 \mathrm{MPa})$, the system is also more stable than pure $\mathrm{CH}_{4}$ hydrate, however at higher pressures where hydrates are in equilibrium with a denser supercritical fluid, pure $\mathrm{CH}_{4}$ hydrates are more stable. 


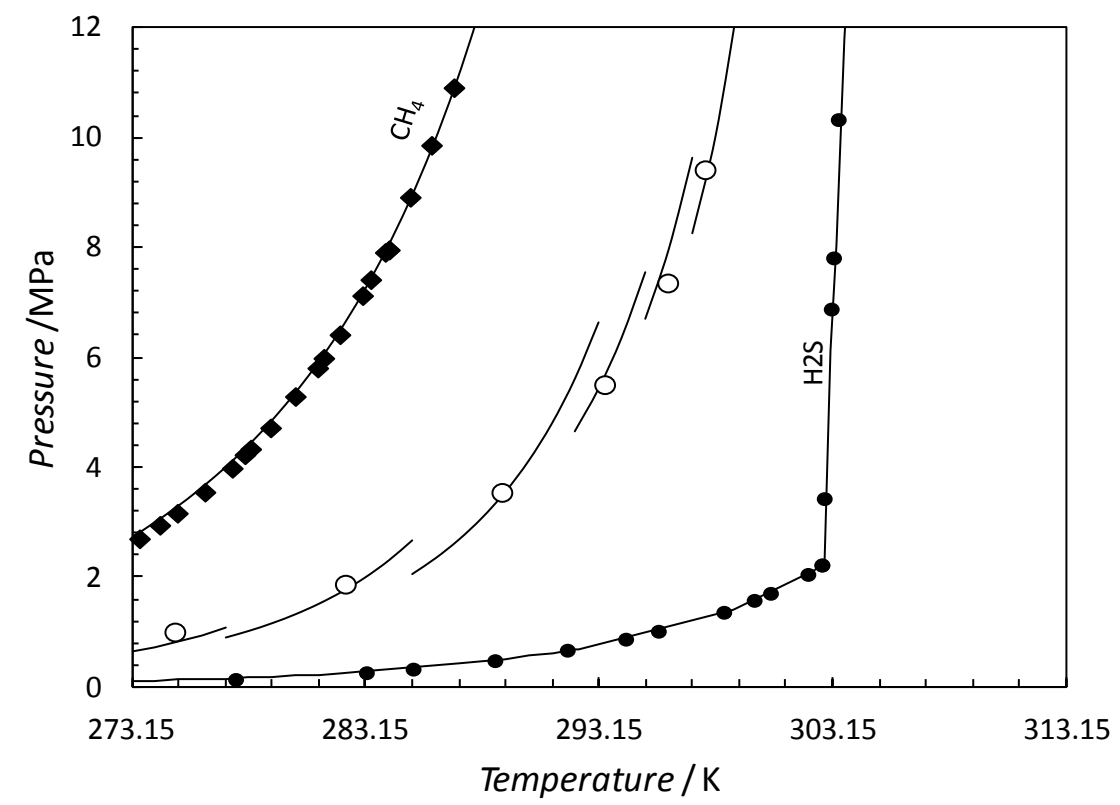

Figure 9. Experimental and predicted hydrate stability of 80 mole $\% \mathrm{CH}_{4}+20$ mole $\% \mathrm{H}_{2} \mathrm{~S}$ system in equilibrium with liquid water. (O), pure $\mathrm{H}_{2} \mathrm{~S}$ hydrate stability zone (Selleck et al. 1952); (O): 80 mole $\%+20$ mole $\% \mathrm{H}_{2} \mathrm{~S} ;(\diamond)$, pure $\mathrm{CH}_{4}$ hydrate stability zone (Marshall et al. 1964). Predictions for the mixtures were performed for the reported aqueous mole fraction.

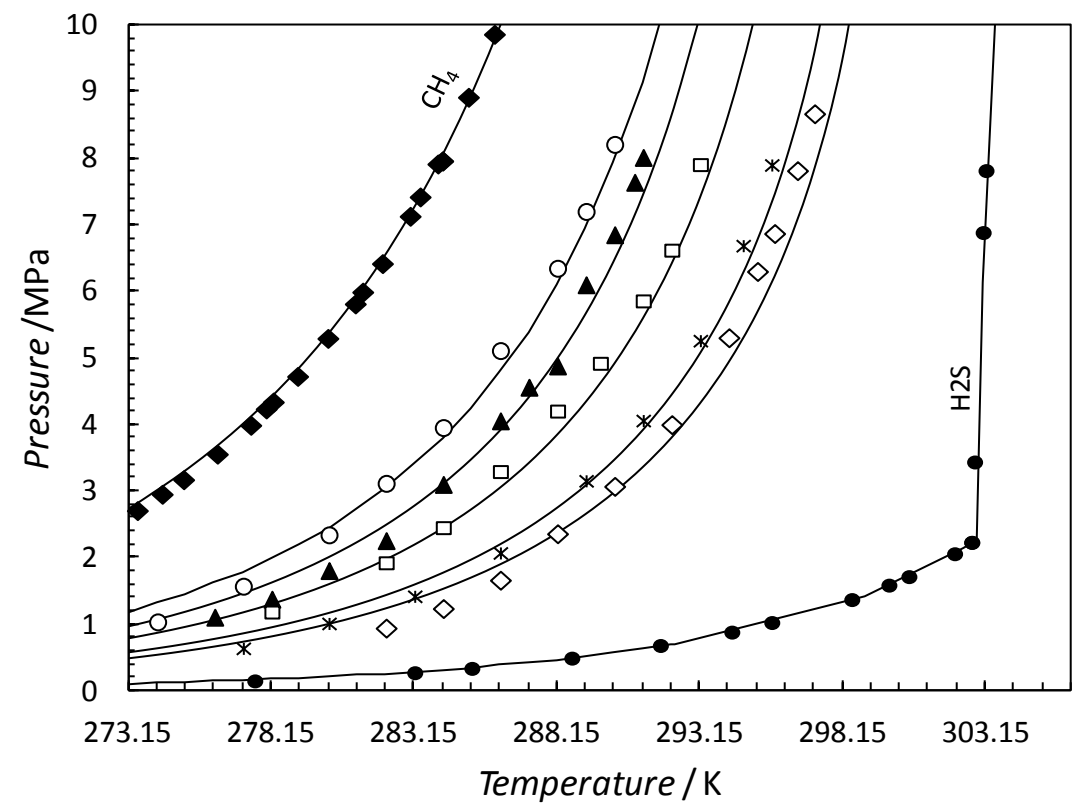

Figure 10. Experimental and predicted hydrate stability of the ternary $\mathrm{CH}_{4}+\mathrm{H}_{2} \mathrm{~S}+\mathrm{CO}_{2}$ system in equilibrium with liquid water. (O), pure $\mathrm{H}_{2} \mathrm{~S}$ hydrate stability zone (Selleck et al. 1952); $(\diamond)$, pure $\mathrm{CH}_{4}$ hydrate stability zone (Marshall et al. 1964); $\left.\diamond\right) 75.48$ mole\% $\mathrm{CH}_{4}+$ 6.81 mole \% $\mathrm{CO}_{2}+17.71$ mole\% $\mathrm{H}_{2} \mathrm{~S}$ (Sun et al., 2003); (O):87.65 mole\% $\mathrm{CH}_{4}+7.4$ mole\% $\mathrm{CO}_{2}+4.95$ mole $\% \mathrm{H}_{2} \mathrm{~S}$ (Sun et al., 2003); ( $\left.\mathbf{\Delta}\right): 82.45$ mole $\% \mathrm{CH}_{4}+10.77$ mole $\% \mathrm{CO}_{2}+$ 6.78 mole\% $\mathrm{H}_{2} \mathrm{~S}$ (Sun et al., 2003) ); ( $\square$ ):82.91 mole\% $\mathrm{CH}_{4}+7.16$ mole\% $\mathrm{CO}_{2}+9.93$ mole\% $\mathrm{H}_{2} \mathrm{~S}$ (Sun et al., 2003) ; (*):75.48 mole\% $\mathrm{CH}_{4}+6.81$ mole\% $\mathrm{CO}_{2}+17.71$ mole\% $\mathrm{H}_{2} \mathrm{~S}$ (Sun et al., 2003). 


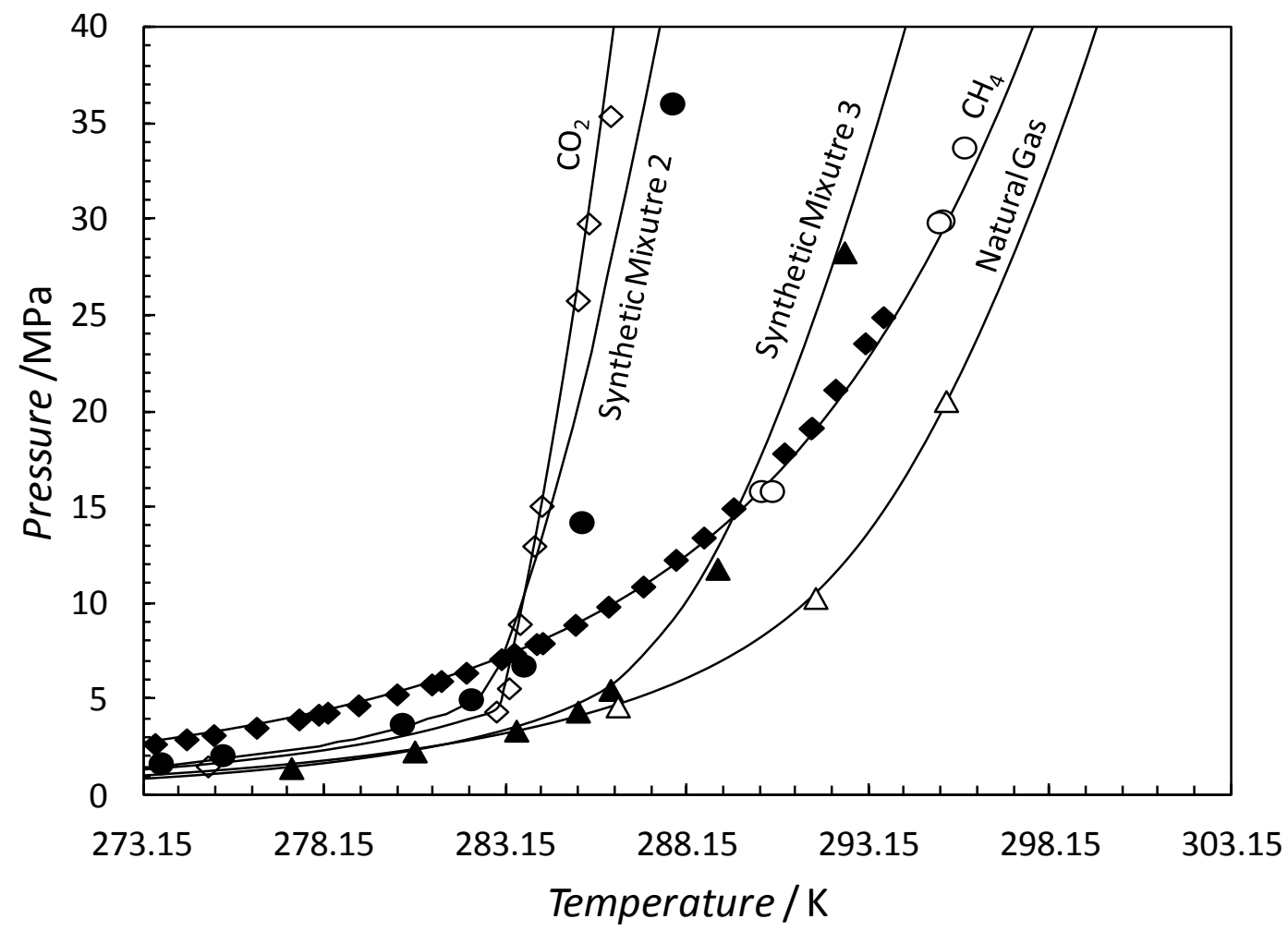

Figure 11. Experimental and predicted hydrate stability of some selected acid gas systems in equilibrium with liquid water. $(\diamond)$, pure $\mathrm{CO}_{2}$ hydrate stability zone (Chapoy et al. 2011); $(\bigcirc)$ : pure $\mathrm{CH}_{4}$ hydrate stability zone (Nixdorf and Oellrich, 1997);( ), pure $\mathrm{CH}_{4}$ hydrate stability zone (Marshall et al. 1964). ( $\triangle$ ), Natural gas hydrate stability zone (Chapoy and Tohidi, 2011).

Hydrate dissociation measurements in absence of a free water phase (dry systems) are difficult to measure by conventional techniques; the alternative is to measure the water content in the fluid phase in equilibrium with hydrates. Unfortunately data for acid gas systems are limited and the few data references available are not in agreement. Experimental data on water contents for $\mathrm{CO}_{2}$ in equilibrium with hydrates from 223.15 to $263.15 \mathrm{~K}$ up to $10 \mathrm{MPa}$ have been measured by Burgass et al. (2014). Chapoy et al. (2013) have reported water content at $15 \mathrm{MPa}$ from 233.15 to $288.15 \mathrm{~K}$. Song and Kobayashi have reported measurements of water content in presence of $\mathrm{CO}_{2}$. However, the reliability of these studies has been recently questioned as seen in Figure 12, some of the data reported by Song and Kobayashi (1984) show large deviations with the developed models and the available literature data.

For multicomponent acid gas mixtures at low temperatures, only data from our laboratory are available. Experimental water content data in equilibrium with hydrates for pure $\mathrm{CO}_{2}$ and 2 multi-component systems (synthetic mixtures $2 \& 3$ ) are plotted along with predictions of the thermodynamic model in Figure 12. As can be seen from the figure the experimental and predicted data are in good agreement with some deviation $(\mathrm{AAD} \approx 5 \%)$. As expected, less water can be dissolved in the multicomponent systems than in pure $\mathrm{CO}_{2}$, because the amount of water that can be dissolved in hydrocarbons is lower than liquid $\mathrm{CO}_{2}$ at the same temperature and pressure. As seen in this figure, the water contents for the synthetic mixtures are between the water contents of pure $\mathrm{CO}_{2}$ and pure $\mathrm{CH}_{4}$, with the water content in mixture 3 (lower $\mathrm{CO}_{2}$ content) closer to pure $\mathrm{CH}_{4}$. 

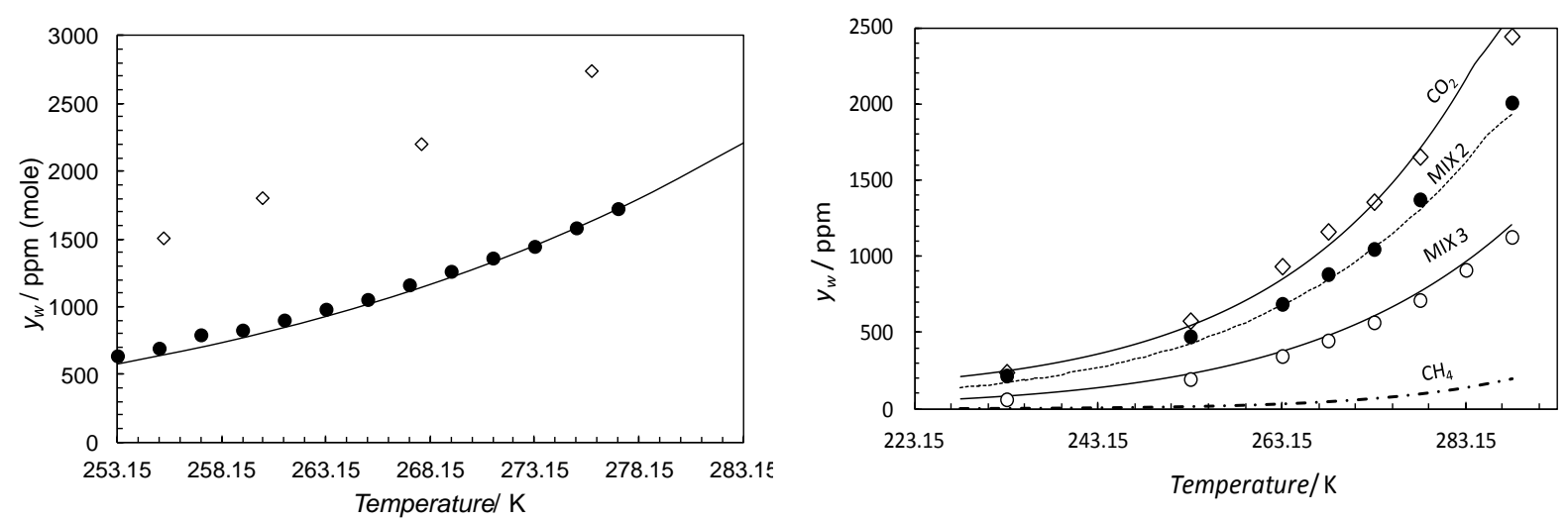

Figure 12. Water content of $\mathrm{CO}_{2}$-rich fluids. Figure on the left: Water content of $\mathrm{CO}_{2}$ in equilibrium with hydrates at $13.79 \mathrm{MPa}$ and different temperatures. (O): Chapoy et al. (2011); $(\diamond)$ : data from Song and Kobayashi (1984). Figure on the right: Experimental water content data and predictions for the water content of pure $\mathrm{CH}_{4}$, pure $\mathrm{CO}_{2}$ and synthetic mixures $2 \& 3$ at $15 \mathrm{MPa}$ and different temperatures.

The experimental and modelling results for the viscosity of the synthetic mixtures are plotted in Figures 13 and 14. All experiments for the streams were conducted at pressures above saturation or in the supercritical region and then at low pressures, i.e., in the single gas phase region. The viscosity of each conducted test was calculated using the modified Pedersen model. As can be seen from the figure, the model predictions and experimental data are in good agreement. Both in the liquid and the supercritical regions, the viscosity is increasing with pressure and decreasing with temperature. In the vapour region, pressure has a weak effect on viscosity and the viscosity is increasing with temperature as expected for low pressure gaseous systems. Viscosities of a "typical" natural gas (low $\mathrm{CO}_{2}$ concentration) were also added in Figure 14 for comparison purposes (data from Kashefi et al., 2013). The viscosities of both the multi-component systems (synthetic mixtures 2 and 3) fall between the viscosities of pure $\mathrm{CO}_{2}$ and of the natural gas from Kashefi et al. (2013).

Densities of the multi-component systems were measured at different pressures and temperatures in gas, liquid and supercritical regions. Both experimental and modelling results with density correction are plotted in Figure 15 for the synthetic mixture 2. By employing the density correction and the SRK-EoS the absolute average deviation is $1.7 \%$. It is interesting to note the peculiar behaviour of density at temperatures above the critical temperature compared to the density of pure $\mathrm{CO}_{2}$ as shown in Figure 16 in which the difference between the density of the two multicomponent mixtures and pure $\mathrm{CO}_{2}$ is plotted at about $423.15 \mathrm{~K}$. For the $\mathrm{CO}_{2}$ mixture at the stated temperature, a maximum reduction in density from that of pure $\mathrm{CO}_{2}$ occurs at a certain pressure. The maximum reductions for the multicomponent systems 2 and 3 are 180 and $300 \mathrm{~kg} / \mathrm{m}^{3}$ at a pressure of around 12 and $14 \mathrm{MPa}$, respectively (i.e., $35 \%$ and $60 \%$ reduction).

Frost point measurements were carried out for the synthetic mixture 2. The experimental data for the system is plotted together with the predicted solid $\mathrm{CO}_{2}$ phase boundary of the mixture and the pure $\mathrm{CO}_{2}$ phase diagram in Figure 17. As seen in the figure, for this system the thermodynamic model using the group contribution $k_{i j}$ tuned on VLE data is in good agreement with the new experimental data. 


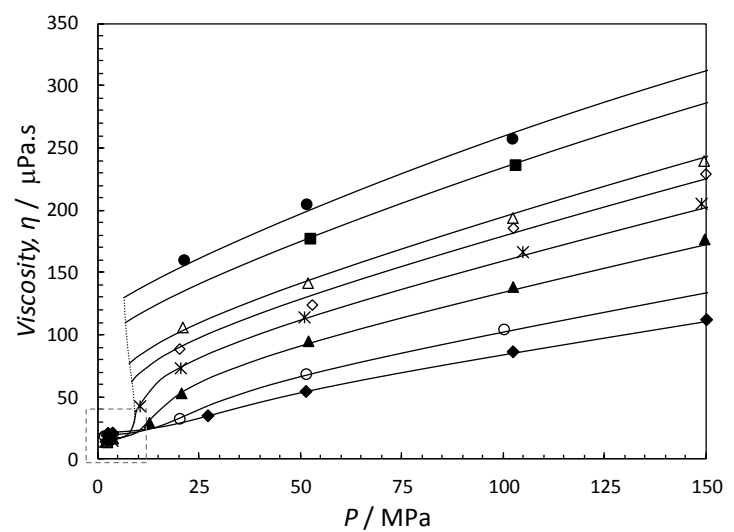

Figure 13. Predicted and experimental viscosity of synthetic mixture 2. Black lines: Predictions using CSP model. Black Dotted lines: Predictions using CSP model at the bubble and dew pressures of the system. Data inside the grey box are plotted in Fig. 9. This work: $(\mathbf{O}), T=243.15 \mathrm{~K}$ $(\square), T=253.15 \mathrm{~K}(\triangle), T=273.15 \mathrm{~K}(\diamond)$, $T=283.15 \mathrm{~K}(\star), T=298.15 \mathrm{~K}(\boldsymbol{\Delta}), T=$ $323.15 \mathrm{~K}(\mathrm{O}), T=373.15 \mathrm{~K}(\diamond), T=$ $423.15 \mathrm{~K}$

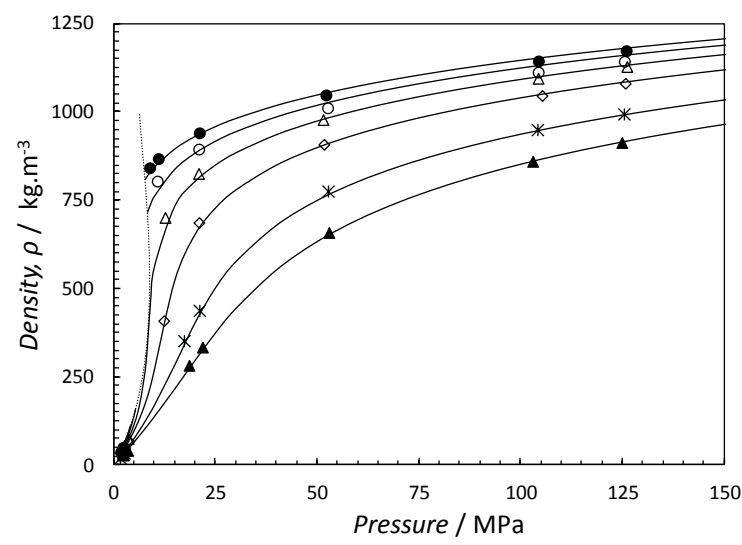

Figure 15. Predicted and experimental density of synthetic mixture 2. Black lines: Predictions using the corrected SRK-EoS model. Black Dotted lines: Predictions using the corrected SRK-EoS model at the bubble and dew pressures of the system. $(\bigcirc), T=273.26 \mathrm{~K}(\bigcirc), T=283.31$ $\mathrm{K}(\triangle), T=298.39 \mathrm{~K}(\diamond), T=323.48 \mathrm{~K}$ (*), $T=373.54 \mathrm{~K}(\boldsymbol{\Delta}), T=423.43 \mathrm{~K}$.

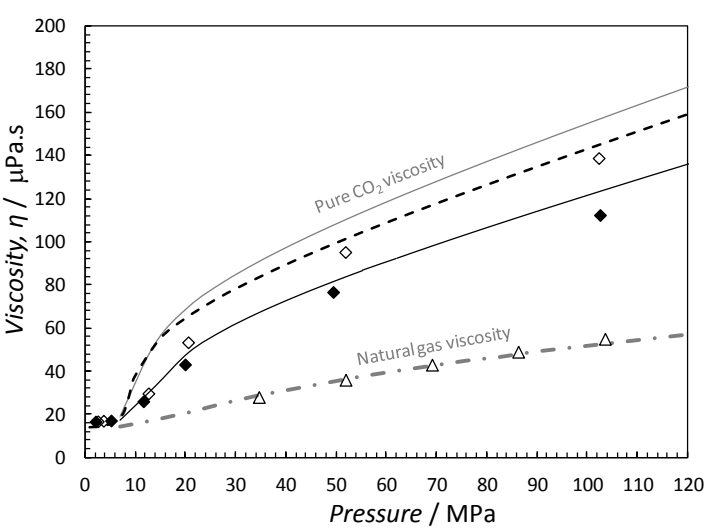

Figure 14. Predicted and experimental viscosity of synthetic mixtures 2 and 3 at 323.15 K. Black and dotted lines: Predictions using the modified CSP model. Grey lines: pure $\mathrm{CO}_{2}$ viscosity. Grey broken lines: Predictions using the original CSP model. $(\diamond)$, synthetic mixture 2; $(\diamond)$,synthetic mixture 3; $(\triangle)$ data from Kashefi et al. (2013) for a Natural gas (in mole\% $\mathrm{C} 1: 88.83 ; \mathrm{C} 2$ : 5.18; C3:1.64; iC4: 0.16; nC4: 0.27; iC5: 0.04; $\mathrm{CO} 2: 2.24 ; \mathrm{N} 2: 1.6)$

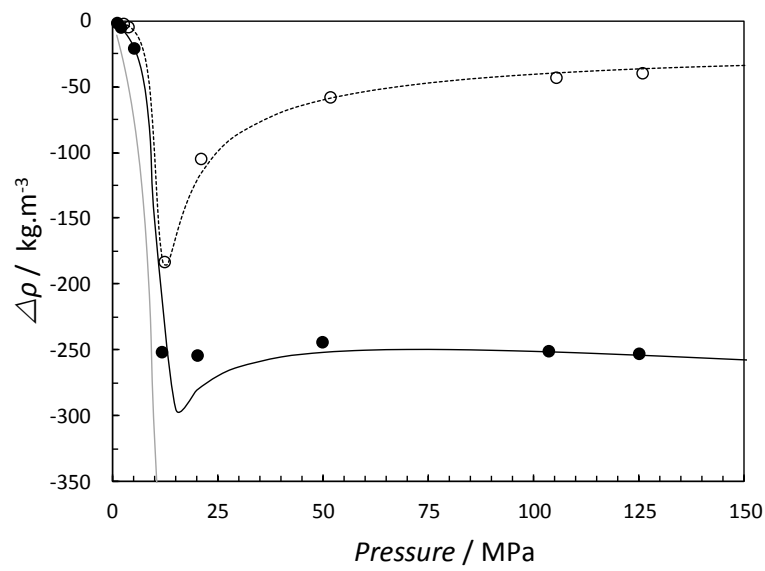

Figure 16. Predicted and experimental density difference $\triangle \rho=\rho^{\mathrm{MIX}}-\rho^{\mathrm{CO} 2}$, between synthetic mixture $2(0)$,synthetic mixture 3 (O)and pure $\mathrm{CO}_{2}$ density at $323.15 \mathrm{~K}$. Lines: Predictions using the corrected SRK-EoS model (Grey line is for methane). 


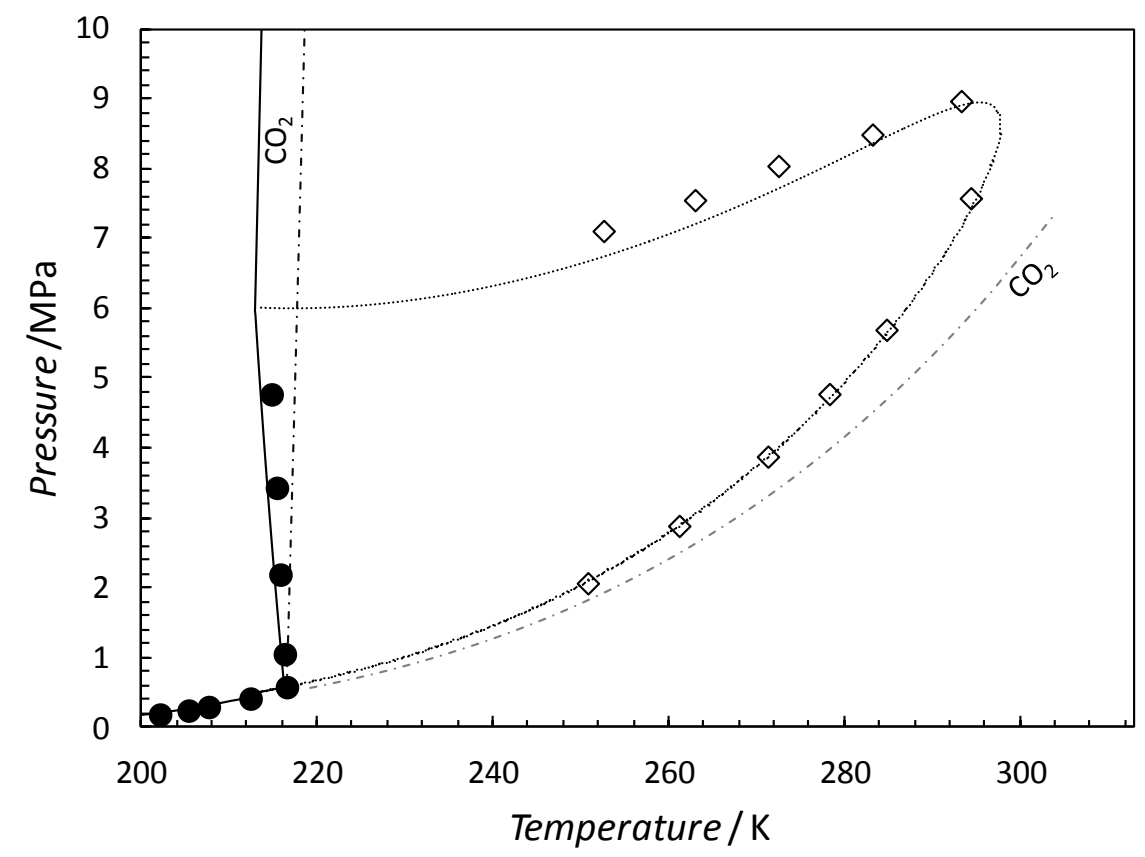

Figure 17. Experimental and predicted phase envelope of the synthetic mixture 2. $(\diamond)$, bubble/dew points. (O), Frost points. Black lines: bubble lines predictions using the SRK-EoS; Dotted black lines: dew lines predictions using the SRK-EoS; Grey broken lines: phase diagram of pure $\mathrm{CO}_{2}$.

\subsection{Conclusions}

Knowledge on the phase behaviour and thermophysical properties of $\mathrm{CO}_{2}$-rich and acid gas systems is of great importance for CCS and developing sour gas reservoirs, as well as testing predictive models. However, limited published data sets are available for such systems. In this communication the phase behaviour and some properties of different acid gas streams have been studied, such as the phase envelope, the hydrate stability, dehydration requirement, viscosity and density of the mixture. Models have been developed to calculate and predict these properties.

Future work will concentrate on the determination/measurement and modelling of properties for other types of natural gases (different $\mathrm{CO}_{2}$ concentrations, impact of $\mathrm{H}_{2} \mathrm{~S}$, etc.).

\section{Acknowledgements}

This research work was part of a Joint Industrial Project (JIP) conducted jointly at the Institute of Petroleum Engineering, Heriot-Watt University and the CTP laboratory of MINES ParisTech. The JIPs supported by Chevron, GALP Energia, Linde AG, OMV, Petroleum Experts, Statoil, TOTAL and National Grid Carbon Ltd, which is gratefully acknowledged. The participation of National Grid Carbon in the JIP was funded by the European Commission's European Energy Programme for Recovery. The authors would also like to thank the members of the steering committee for their fruitful comments and discussions.

\section{References}

Burgass, R., Chapoy, A., Duchet-Suchaux, P., Tohidi, B. "Experimental water content measurements of carbon dioxide in equilibrium with hydrates at (223.15 to 263.15) 
$\mathrm{K}$ and (1.0 to 10.0) MPa", The Journal of Chemical Thermodynamics, 69, 1-5 (2014).

Burgess M.P., Germann R.P., "Physical properties of hydrogen sulfide water mixtures", AIChE J. 15, 272-275 (1969)

Chapoy, A., Mohammadi, A., Tohidi, B., Valtz, A., Richon, D. "Effect Experimental Measurement and Phase Behavior Modeling of Hydrogen Sulfide-Water Binary System" Ind. Eng. Chem. Res.44, 7567-7574 (2015).

Chapoy, A., Burgass, R., Tohidi, B., Austell, J.M., Eickhoff, C., "Effect of Common Impurities on the Phase Behavior of Carbon-Dioxide-Rich Systems: Minimizing the Risk of Hydrate Formation and Two-Phase Flow" SPE J. 16, 921-930 (2011).

Chapoy, A., Tohidi, B.; "Hydrates in High Inhibitor Concentration Systems", GPA Research Report 205, RR-205, (2011).

Chapoy, A., Haghighi, H., Burgess, R., Tohidi, B., "On the Phase Behaviour of the Carbon Dioxide - Water Systems at Low Temperatures: Experimental and Modelling", J. Chem. Therm. 47, 6-12 (2012).

Chapoy, A., Nazeri, M., Kapateh, M., Burgass, R., Coquelet, C., Tohidi, B., "Effect of impurities on thermophysical properties and phase behaviour of a $\mathrm{CO}_{2}$-rich system in CCS”, International Journal of Greenhouse Gas Control, 19, 92-100 (2013).

Chapoy, A., Burgass, R., Alsiyabi, I., Tohidi, B., "Hydrate and Phase Behavior Modeling in CO2-Rich Pipelines", J. Chem. Eng. Data 60, 447-453 (2015).

Duan, Z., Sun, R. "An improved model calculating $\mathrm{CO}_{2}$ solubility in pure waterand aqueous $\mathrm{NaCl}$ solutions from 273 to $533 \mathrm{~K}$ and from 0 to 2000 bar", Chemical Geology 193, 257-271 (2003).

Duan, Z., Sun, R., Liu, R., Zhu, C. "Accurate Thermodynamic Model for the Calculation of H2S Solubility in Pure Water and Brines”, Energy \& Fuels, 21, 2056-2065 (2007)

Ely, J.F., Magee, J.W., Haynes, W.M.. "Thermophysical properties for special high CO2 content mixtures". Research Report RR-110, Gas Processors Association, Tulsa, OK (1987).

Fenghour, A., Wakeham, W.A., Vesovic, V., "The Viscosity of Carbon Dioxide". J. Phys. Chem. Ref. Data. 27, 31-44 (1998).

Gillespie, P.C., Wilson, G.M. "Vapor-liquid and liquid-liquid equilibria: watermethane, water-carbon dioxide, water-hydrogen sulfide, water-n-pentane, watermethane-n-pentane", Research report RR-48, Gas Processors Association, Tulsa (1982).

Haghighi, H., Chapoy, A., Burgess, R., Tohidi, B. "Experimental and thermodynamic modelling of systems containing water and ethylene glycol: Application to flow assurance and gas processing". Fluid Phase Equilib. 276, 24-30 (2009).

Hajiw, M., Etude des Conditions de Dissociation des Hydrates de Gaz en Présence de Gaz Acides / Hydrate Mitigation in Sour and Acid Gases, PhD dissertation, 2014.

Hajiw, M., Chapoy, A., Coquelet, C. "Effect of acide gases on the methane hydrate stability zone", $8^{\text {th }}$ International Conference on Gas Hydrates (ICGH8-2014), Beijing, China, 28 July - 1 August, 2014.

Hanley, H.J.M., McCarty, R.D., Haynes, W.M., "Equation for the viscosity and thermal conductivity coefficients of methane", Cryogenics 15, 413-417 (1975).

Hou, S-X., Maitland G.C., Trusler J.P. M., "Measurement and modeling of the phase behavior of the (carbon dioxide+ water) mixture at temperatures from $298.15 \mathrm{~K}$ to 448.15 K". The Journal of Supercritical Fluids., 73, 87-96 (2013).

Jamaluddin A. K. M.,Bennion, D.B., Thomas, F.B., Clark, M.A., "Acid/Sour Gas Management in the Petroleum Industry", SPE 49522, (1998). 
Jaubert, J-N., Privat, R., "Relationship between the binary interaction parameters ( $k i j)$ of the Peng-Robinson and those of the Soave-Redlich-Kwong equations of state: Application to the definition of the PR2SRK model", Fluid Phase Equilibria 295, 26-37 (2010).

Kashefi, K., Chapoy, A., Bell, K., Tohidi, B., "Viscosity of binary and multicomponent hydrocarbon fluids at high pressure and high temperature conditions: Measurements and predictions", Journal of Petroleum Science and Engineering 112, 153-160 (2013).

King, MB., Mubarak, A., Kim, JD., Bott, TR. "The mutual solubilites of water with supercritical and liquid carbon dioxide". J. Supercrit. Fluids. 5, 296-302 (1992).

Lallemand F. et al. "Solutions for the treatment of highly sour gases", Digital Refining, April 2012.

Longman, L., Burgass, R., Chapoy, A., Tohidi, B., Solbraa, E. Measurement and Modeling of CO2 Frost Points in the CO2-Methane Systems, Journal of Chemical \& Engineering Data, 2011. 56(6), 2971-2975.

Marshall, D. R., Daito, S, Kobayashi, R. "Hydrates at High Pressures: Part I. MethaneWater, Argon-Water, and Nitrogen-Water Systems", AIChE J. 10, 202-205 (1964).

Murad, S., Gubbins, K.E., 1977. Corresponding states correlation for thermal conductivity of dense fluids. Chem. Eng. Sci., 32, 499-505.

Nakayama, T., Sagara, H., Arai, K., Saito, S. "High pressure liquid-liquid equilibria for the system of water, ethanol and 1,1-difluoroethane at 323.2 K". Fluid Phase Equilibria, 38,109-127 (1987).

Nixdorf, J.; Oellrich, L. R. "Experimental determination of hydrate equilibrium conditions for pure gases, binary and ternary mixtures and natural gases", Fluid Phase Equilibria, 139, 325-333 (1997).

Parrish, W.R., Prausnitz, J.M., "Dissociation pressures of gas hydrates formed by gas mixtures", Ind. Eng. Chem. Process. Des. Develop. 11, 26-34 (1972).

Pedersen, K.S., Christensen, P.L., 2007. Phase behaviour of petroleum reservoir fluids. CRC Press, Taylor \& Francis Group.

Selleck, F.T.; Carmichael, L.T.; Sage, B.H., "Phase behavior in the hydrogen sulfide water system", Ind.Eng.Chem. 44(9), 2219-2226 (1952).

Song, K.Y., Kobayashi, R., "The water content of CO2-rich fluids in equilibrium with liquid water and/or hydrates". Research Report RR-88, (1984) Gas Processors Association, Tulsa, OK. Also published in K.Y. Song, R. Kobayashi, Water content of CO2-rich fluids in equilibrium with liquid water or hydrate. Research Report RR99, (1986) Gas Processors Association, Tulsa, OK.

Stringari, P., Valtz, A., Chapoy, A., " Study of factors influencing equilibrium and uncertainty in isochoric hydrate dissociation measurements", $8^{\text {th }}$ International Conference on Gas Hydrates (ICGH8-2014), Beijing, China, 28 July - 1 August, 2014.

Sun, C.Y., "Hydrate Formation Conditions of Sour Natural Gases", J. Chem Eng. Data 48(3) 600-602 (2003).

Tabasinejad, F., Moore R. G., Mehta S. A., Van Fraassen, K. C., Barzin, Y., Rushing J. A., Newsham, K. E., "Water Solubility in Supercritical Methane, Nitrogen, and Carbon Dioxide: Measurement and Modeling from 422 to $483 \mathrm{~K}$ and Pressures from 3.6 to $134 \mathrm{MPa}$ ". Ind. Eng. Chem. Res. 50, 4029-4041 (2011).

Valtz, A., Chapoy, A., Coquelet, C., Paricaud, P., Richon, D. "Vapour - liquid equilibria in the carbon dioxide - water system, measurement and modelling from 278.2 to 318.2 K". Fluid Phase Equilibria. 226, 333-344 (2004). 
Van der Waals, J.H. Platteeuw, J.C., "Clathrate solutions", Adv. Chem. Phys. 2, 2-57 (1959).

Wiebe, R., Gaddy, VL. "Vapor phase composition of the carbon dioxide-water mixtures at various temperatures and at pressures to $700 \mathrm{~atm}$ ". J. Am .Chem. Soc. 63, 475-477 (1941). 